\title{
Algorithm for complex diagnostics of cattle emerging diseases
}

\author{
E.V. Pechura ${ }^{1, *}, A . P$. Poryvayeva $^{1}$, N.A. Bezborodova ${ }^{1}$, and Ya.Yu. Lysova ${ }^{1}$ \\ ${ }^{1}$ Federal State Budgetary Institution "Ural Federal Agrarian Scientific Research Center of the Ural \\ Branch of the Russian Academy of Sciences", 620142 Yekaterinburg, Russia
}

\begin{abstract}
Problems of detailed studies into the epizootic process of infectious diseases of farm animals, mechanisms of interaction of pathogenic microorganisms with macroorganisms, as well as issues of health improvement and protection of animal populations from epizootically significant diseases are acute for veterinary science and practice. As a result of the studies the spectrum of pathogens in parasite cenosis on the territory of the entity of the Russian Federation was identified. The species composition of pathogens in cases of noninfectious pathology and infectious diseases in young cattle is specified. The pathogens are represented by Staphylococcus spp., Streptococcus spp., E. coli. K-99, pathogenic fungi Aspergillus spp.and yeast fungi Candida albicans, $B H V-1$ and $B V D V$. A database was compiled to upgrade the methodology of analyzing epizootological studies. The development and implementation of health and health-related programs has decreased the occurence of acute intestinal infections and respiratory tract infections in young cattle by more than 1.3 times. Multi-level epizootic surveillance of farm animal populations can prevent the occurrence and spread of particularly dangerous infections, eliminate managed infections, downgrade the risk of post-infectious complications and improve the economic efficiency of the livestock industry as a whole.
\end{abstract}

\section{Introduction}

The implementation in Russia of the State Program for the development of the agricultural sector and regulation of the market of agricultural products, raw materials and food for 2013-2020 has resulted in a new round of intensification of technology for the production of livestock goods. One of the most significant factors accounting for the economic efficiency and profitability of the livestock industry is cattle biological wellbeing. Under current conditions of animal breeding, the biological well-being of farm animals is ensured by a complex set of veterinary and sanitary as well as zoohygienic techniques $[1,2]$. Nevertheless, the intensification of technological processes and high concentration of livestock in a limited area result in changes in the characteristics of the microclimate and microbiota of animal housing [1, 3]. Continuous exposure to

\footnotetext{
*Corresponding author: ev-pechura@bk.ru
} 
"technological stress factors" triggers breakdowns of adaptive mechanisms in the animal's body, which increases the susceptibility of animals to infectious and parasitic diseases [3, 4]. Moreover, as a result of the globalization of international relations, the risk of introduction of enzootic diseases and the range of pathogenic pathogens has grown by many times $[1,2,5]$.

Issues of biological well-being of farm animals and their protection from epizootically significant diseases are especially acute for veterinary science and practice. The introduction of multi-level epizootic monitoring of farm animal populations is able to prevent the occurrence and spread of particularly dangerous infections, eliminate managed infections, downgrade the risk of post-infectious complications, and enhance the economic efficiency of the livestock industry as a whole [5, 6-8]. The effectiveness of epizootic monitoring at many stages is accounted for by the methodological and instrumental base, material and technical equipment of veterinary laboratory practice. Developing an algorithm for complex diagnostics of cattle infectious diseases as an effective instrument in solving problems concerning the biological well-being of farm animals is a pressing and essential challenge for controlling and managing the epizootic process.

\section{Materials and methods}

The research was performed in the Department of monitoring and predicting infectious diseases and in the Department of veterinary laboratory diagnostics with the testing laboratory of the Ural Federal Agrarian Research Center of the Ural Branch of the Russian Academy of Sciences in the framework of Direction 160 of the Program of fundamental scientific research of the state academies of sciences "Molecular biological and nanobiotechnological techniques for creating new-generation biologics, technologies and methods of their application to combat particularly dangerous infectious, parasitic and noninfectious animal diseases (2013-2020)" and Project 8-8-9-16 of the Russian Academy of Sciences "Ecological and biological peculiarities of the epizootic process formation depending on molecular genetics and immunobiological qualities of pathogens of infectious diseases of farm animals" (2018-2019)".

The object of the study was cattle bred at large commercial farms. The biological materials were blood $(n=249)$, blood serum $(n=317)$ and feces $(n=83)$. Biological materials were collected from 3 agricultural organizations situated on the territory of the Ural Federal District.

Serological screening of biological material was performed (1) for acute respiratory viral infections in cattle $(B H V-1, B V D V, B P I V 3)$ - in the reaction of inhibition of hemagglutination and in the reaction of indirect hemagglutination using industrial erythrocyte diagnostics manufactured in the Russian Federation; (2) using solid-phase ELISA method using testing kits by IDEXX Laboratories, Inc, USA: "IBR gB Blocking Ab Test"; "IBR gE Ab Test"; "Chlamydiosis Total Ab Test"; "BVDV Total Ab Test"; "RSV IgG Ab Test"; "PI-3 Ab Test"; "Bovine Viral Diarrhoea Virus (BVDV) Antigen Test Kit/Serum Plus"; "Rota-Corona-K99 Antigen Test"; "Neospora caninum Ab Test". Research results were recorded on a reader SUNRISE (Tecan, Austria). The production reactions were performed in the Biosafety boxes (ESCO, Korea).

Molecular genetic studies of the bioassays were carried out by polymerase chain reaction (PCR). Such genomes as Bovine herpes virus (type 1), Bovine virus diarrhoea, Chlamydophila abortus, Chlamydophila pecorum, Mycoplasma bovis, Mycoplasma bovigenitalium and Toxoplasma gondii were identified using commercial reagent kits (manufactured in Russia). PCR was carried out using the Applicede Biosystems 2720 thermal cycler (Singapore) with the account of the results in the electrophoretic version 
using a Mini-Sub Cell GT camera (Bio-Rad, USA) and interpreting the results using the gel Doc XR+ documentation (Bio-Rad, USA). Real-time amplification was carried out using Rotor-Gene 3000 (Corbett Life Science, Australia).

Bacteriological studies of biological samples from cattle were conducted in accordance with the guidelines of "Methods of bacteriological research of opportunistic microorganisms in clinical microbiology - MUK 4.2.1890-04". The results of the study were recorded using Axio Observer microscope (Zeiss, Germany).

Coprological studies of biomaterial samples were performed by the method of sedimentation and flotation diagnostics in accordance with GOST 25383-82 "Methods of laboratory diagnostics of coccidiosis" and GOST 54627-2011 "Methods of laboratory diagnostics of helminthiasis". The results of the study were recorded using "Biolam 13" and "Mikmed - 5" microscopes manufactured in the Russian Federation.

The received data was processed in Microsoft Excel included into Microsoft Office Pro software package.

\section{Results and discussion}

According to the official veterinary reports in the Sverdlovsk region, more than 70 thousand heads of cattle annually suffer from various diseases. Up to $75.2 \%$ of the total number of sick animals are young. The first place in the nosological structure of diseases of young cattle is taken by diseases of the gastrointestinal tract $(21.1 \pm 2.3 \%)$, the second place - by diseases of the respiratory tract $(12.7 \pm 2.1 \%)$, the third one - diseases of non-infectious pathology $(8.4 \pm 1.2 \%)$. According to the Department of Veterinary Medicine of the Sverdlovsk Region and the results of their own earlier studies, infectious etiology in diseases of the respiratory tract is diagnosed in $12-13 \%$ of cases; in diseases of the gastrointestinal tract - in 15-18\% of cases; in diseases of non-infectious pathology - in less than $2 \%$ [9].

The performed retrospective and operational analysis of data on diagnostic studies, for example, only in relation to diseases of the respiratory tract of infectious etiology has revealed that their volume is insufficient (Table 1).

Table 1. Dynamics of diagnostic studies on pathogens of bovine respiratory tract diseases

\begin{tabular}{|l|c|c|c|c|c|}
\hline \multirow{2}{*}{$\begin{array}{c}\text { Territorial and } \\
\text { administrative } \\
\text { entities } \\
\begin{array}{c}\mathrm{N}-\text { number of farms } \\
\text { examined) }\end{array}\end{array}$} & $\begin{array}{c}\text { Average number } \\
\text { of livestock on the } \\
\text { farm }\end{array}$ & \multicolumn{3}{|c|}{$\begin{array}{c}\text { The number of diagnostic studies performed in } \\
\text { relation to pathogens of bovine respiratory tract, } \%\end{array}$} \\
\cline { 3 - 6 } $\begin{array}{l}\text { Beloyarsky district } \\
\mathrm{N}=6\end{array}$ & $1815,5 \pm 10,5$ & 2017 & 2018 & 2019 & 2020 \\
\hline $\begin{array}{l}\text { Kamyshlovky district } \\
\mathrm{N}=8\end{array}$ & $857,5 \pm 11,5$ & 1,6 & 1,8 & 1,9 & 1,5 \\
\hline $\begin{array}{l}\text { Pyshminsky district } \\
\mathrm{N}=5\end{array}$ & $2179,5 \pm 10,5$ & 1,4 & 1,2 & 1,4 & 1,2 \\
\hline $\begin{array}{l}\text { Sysertsky district } \\
\mathrm{N}=5\end{array}$ & $1461,5 \pm 12,5$ & 1,8 & 1,7 & 1,8 & 1,6 \\
\hline $\begin{array}{l}\text { Shalinsky district } \\
\mathrm{N}=4\end{array}$ & $663,5 \pm 8,5$ & 0,8 & 3,2 & 2,7 & 2,2 \\
\hline
\end{tabular}




\begin{tabular}{|l|c|c|c|c|c|}
\hline $\begin{array}{c}\text { Total } \\
\mathrm{N}=28\end{array}$ & $1406,5 \pm 10,7$ & 1,56 & 2,06 & 2,02 & 1,68 \\
\hline
\end{tabular}

The main diagnosed etiological agents of the respiratory tract diseases are Pasterella spp. (in $12-20 \%$ of cases) and viruses of the ARVI group (in $8-10 \%$ of cases). Similar findings were seen when the data on diagnostic studies for gastrointestinal diseases in young cattle was reviewed. The analysis of the laboratory diagnostic methods applied for diseases of the respiratory tract and gastrointestinal diseases has shown that the traditional method of serological testing is mainly used (Fig. 1).

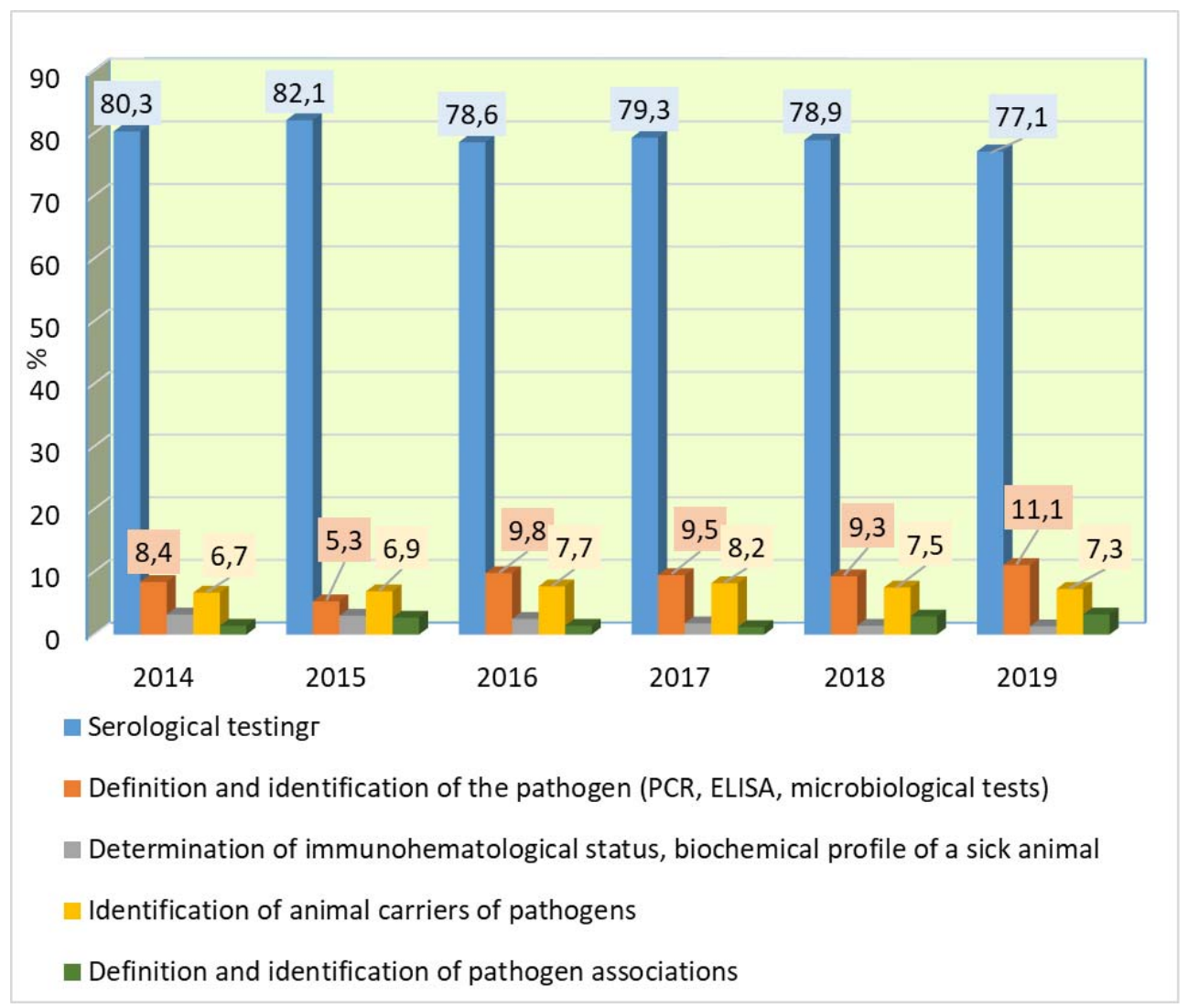

Fig. 1. Laboratory tests applied for diagnostics of diseases of the respiratory tract and gastrointestinal diseases in cattle (2015-2019), \%

The diagnostic criterion in serological reactions is considered to be an increase in the titer of antibodies to the pathogen by 4 times or more. For establishing the etiological agent of the disease, it is required to study paired samples of blood serum taken at 14 days intervals. Nevertheless, a number of pathogens, such as $B H V-1$ and representatives of Chlamydophila spp. are capable to suppress the body's immunoreactivity with a disorder in the synthesis of globulin-type proteins. [2, 5].

As is commonly known, fundamental veterinary science refers infectious diseases of cattle to parasitocenoses. Parasitocenosis is a collection of prions, viruses, microorganisms, zooparasites and other components of biota living inside and on the covers of a macro-organism that is their host and causing it different degrees of harm. [10]. Thus, epizootic well-being of territories, successful containment and management of the epizootic 
process cannot be guaranteed without constant study and analysis of the structure of parasitocenoses, mechanisms of combined effects of parasitocenosis components on the organism of the "host" [11-13].

The above underlines the necessity of detailed consideration of the issue of developing algorithms for complex diagnostics of animal diseases allowing us to fully characterize the antigenic structure of parasitocenosis and assess the risk of post-infectious complications and pathological conditions in animals. For solving this issue a team of authors from the Department of monitoring and predicting of the Ural Federal Agricultural Research Center of the Ural Branch of the Russian Academy of Sciences designed a scheme for complex diagnostics of diseases of the respiratory tract and diseases of the gastrointestinal tract of bovine (figure 2).

Analysis of the nosological structure of cattle diseases in the surveyed farm

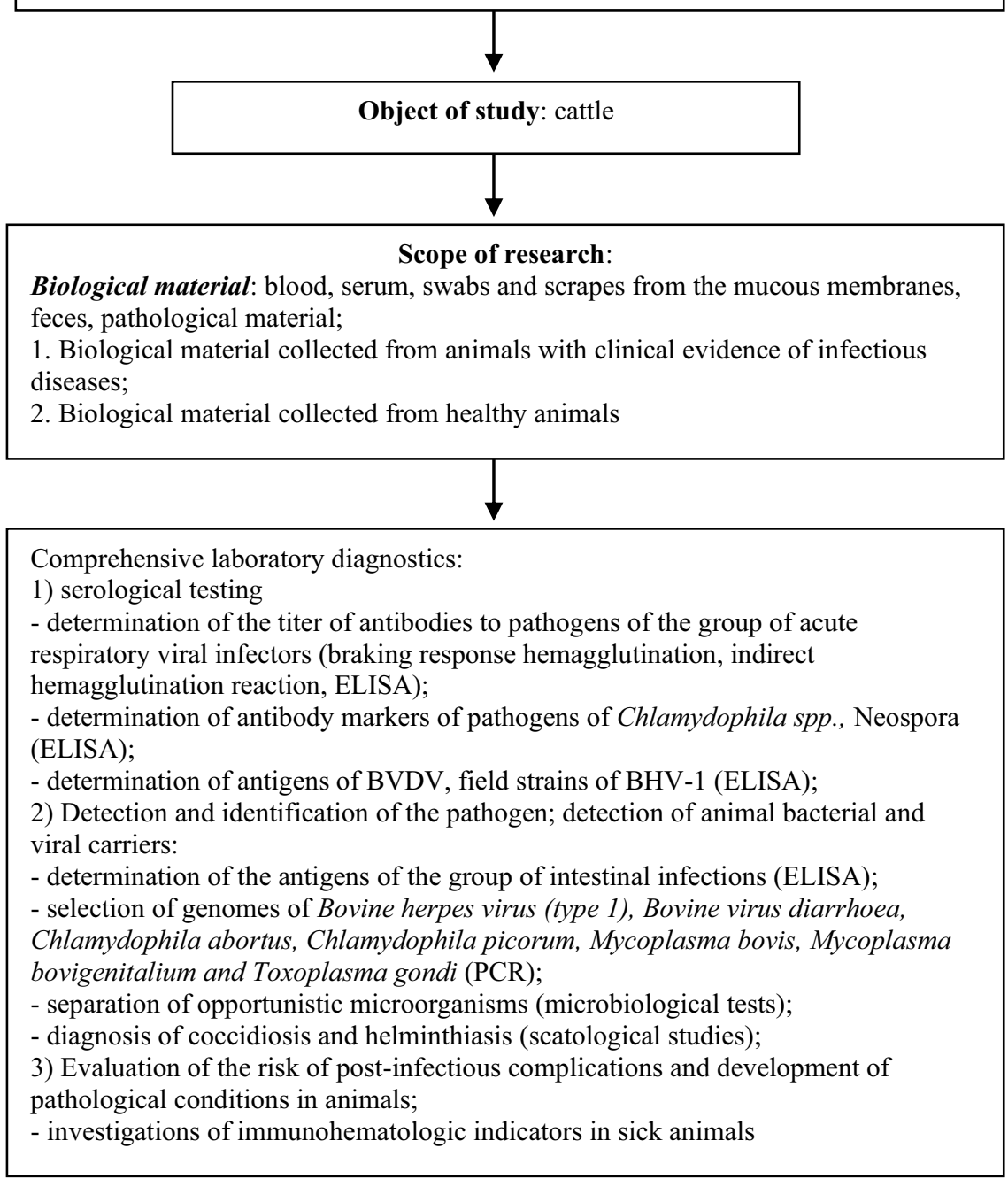

Fig. 2. Algorithm for complex diagnostics of diseases of the respiratory tract and diseases of the gastrointestinal tract of cattle. 
Efficiency of the developed algorithm for diagnostics of infectious etiology of cattle diseases was studied at limited subpopulations of calves from three farms of the Ural Federal District. At the first stage of the study, the nosological structure of diseases in young cattle at the surveyed farms was observed. In accordance with the data of the farm-1 veterinary service "diseases of non-infectious etiology" such as hypotrophy and mineral metabolism disorders were found in calves in $66.4 \%$ of cases. The percentage of calves diagnosed with "diseases of the gastrointestinal tract" was $22.1 \%$, "diseases of the respiratory tract" - less than $12 \%$. The percentage distribution of nosological forms of diseases of young cattle at farm- 2 and farm- 3 is presented in the table 2 .

Table 2. Nosological forms of diseases of young cattle in accordance with the data of the veterinary service of the examined farms of the Ural Federal District.

\begin{tabular}{|c|c|c|c|}
\hline An examined farm & $\begin{array}{c}\text { Diseases of non- } \\
\text { infectious etiology }\end{array}$ & $\begin{array}{c}\text { Diseases of the } \\
\text { respiratory tract }\end{array}$ & $\begin{array}{c}\text { Diseases of the } \\
\text { gastrointestinal tract }\end{array}$ \\
\hline Farm $-1(\mathrm{n}=68)$ & $66,4 \%$ & $11,5 \%$ & $22,1 \%$ \\
\hline Farm $-2(\mathrm{n}=73)$ & $38,4 \%$ & $17,8 \%$ & $43,2 \%$ \\
\hline Farm $-3(\mathrm{n}=108)$ & $20,4 \%$ & $73,1 \%$ & $6,5 \%$ \\
\hline
\end{tabular}

The data presented in Table 2 shows that the percentage distribution of nosological forms is individual for each farm and does not give a reliable estimate of the etiological agents of diseases of calves.

The data received at the second stage of the "Complex laboratory diagnostics" study is shown in Table 3.

Table 3. Findings of the study of biomaterial obtained from young cattle.

\begin{tabular}{|c|c|c|c|}
\hline \multirow{2}{*}{$\begin{array}{l}\text { Nosological } \\
\text { forms }\end{array}$} & \multicolumn{3}{|c|}{ Diagnosed antigens and their associations (\%) } \\
\hline & Farm -1 & Farm -2 & Farm -3 \\
\hline $\begin{array}{c}\text { Diseases of } \\
\text { non-infectious } \\
\text { etiology }\end{array}$ & $\begin{array}{l}10,3 \%-\text { Staphylococcus } \\
\text { spp. }+ \text { Streptococcus spp. } \\
2,3 \%-\text {-Eimeria bovis }\end{array}$ & $\begin{array}{l}\text { 9,4\%- Staphylococcus } \\
\text { spp. }\end{array}$ & $8,9 \%-B V D V$ \\
\hline $\begin{array}{l}\text { Diseases of the } \\
\text { respiratory } \\
\text { tract }\end{array}$ & $\begin{array}{l}5,9 \%-\text { Staphylococcus } \\
\text { spp. } \\
5,6 \%-\text { Staphylococcus } \\
\text { spp.+ Streptococcus } \\
\text { spp.+ E. coli.K-99 }\end{array}$ & $\begin{array}{l}2,1 \%-\text { BPIV3+ } \\
\text { Staphylococcus spp. } \\
2,1 \%-\text { BHV-1 }+ \\
\text { Staphylococcus spp. } \\
3,2 \%-\text { Staphylococcus } \\
\text { spp. }+ \text { Eimeria bovis } \\
10,4 \% \text { Staphylococcus } \\
\text { spp. }+ \text { Streptococcus } \\
\text { spp. }\end{array}$ & 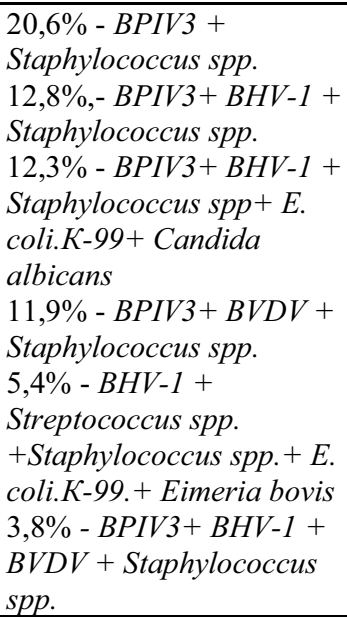 \\
\hline
\end{tabular}




\begin{tabular}{|c|l|l|l|}
\hline & & $20,7 \%-$ \\
& $5 \%-$ bovine rotavirus + & Staphylococcus spp. & \\
& Staphylococcus spp. + & $8,5 \%-$ Staphylococcus & \\
& Streptococcus spp. & spp. + Aspergillus + & \\
Diseases of the & $7 \%-$ bovine coronavirus & Candida albicans & $6,5 \%-$ E. coli.K-99.+ \\
tract & + Staphylococcus spp. + & $8,5 \%-$ Streptococcus & Eimeria bovis \\
& E. coli.K-99 & spp. + E. coli.K-99. + & \\
& $3,1 \%-$ Staphylococcus & Eimeria bovis & \\
& spp. + Streptococcus & $7 \%-$ Staphylococcus & \\
& spp. + Eimeria bovis & spp. + Streptococcus & \\
& & spp. + Aspergillus spp.. & \\
\hline
\end{tabular}

Comprehensive diagnostic investigations to identify the etiological agent determined that in the examined young cattle on farm-1 with three nosological forms under study, infectious pathogens are detected in $39.7 \%$ of cases; on farm-2 - in $71.2 \%$ of cases; on farm-3 - in $81.5 \%$ of cases. Comparative analysis of the findings revealed significant differences in the antigenic composition of farm parasitocenoses. Therefore, pathogenic microorganisms Staphylococcus spp dominated on farm-1. They were detected in $88.9 \%$ of sick calves. Pathogenic microorganisms Streptococcus spp. were found in 59.2\% of cases and, unlike Staphylococcus spp., only in association with other pathogens. Hemolytic E. coli. K-99 was found in $29.6 \%$ of sick calves, also only in associations with other pathogens. Pathogens of the taxonomic group «Viruses», bovine rotavirus and bovine coronavirus, were detected in $11.1 \%$ and $18.5 \%$ cases respectively. Coccidiosis invasion of Eimeria bovis as a «mono» disease is found in 3.8\% of cases; in association with other pathogens- in $7.4 \%$ of cases. Parasitocenosis on the farm with a group "Bacteria + Bacteria" was diagnosed in $55.6 \%$ of cases; "Bacteria + Virus" - in $29.6 \%$; "Bcteria + Coccidia $\gg-$ in $7.4 \%$ of cases.

Pathogenic microorganisms Staphylococcus spp. (88.5\%) also predominated in parasitocenosis in sick calves on farm-2. A mono-infection of bacterial etiology (Staphylococcus spp.) in young animals on farm-2 was found in $42.3 \%$ of cases. Other diagnosed antigens were detected only in associations. The share of pathogenic Streptococcus spp. in parasitocenosis was $36.5 \%$; of hemolytic E. coli. K-99-11.5\%. Pathogenic fungi of the genus Aspergillus were detected as cofactor antigens in $21.1 \%$ of cases and yeast fungi Candida albicans - in $11.5 \%$ of cases. $B H V-1$ was diagnosed in $3.8 \%$ of parasitocenoses, BPIV3-in 3.8\%. Coccidiosis infestation of Eimeria bovis in associations with other pathogens was found in $15.4 \%$ of cases. Parasitocenoses on farm-2 with the "Bacteria + Bacteria" antigen group were found in $15.4 \%$ of cases; "Bacteria + pathogenic fungus" $-21,2 \%$; "Bacteria + Virus $>-7,7 \%$; "Bacteria + Coccidia"- in $17.3 \%$ of cases.

Staphylococcus spp was detected in $81.8 \%$ of parasitocenoses on farm-3; in $75 \%$ it was BPIV3; in 42\% - BHV-1 viruses; in 29.5\% - hemolytic E. coli. K-99; in $19.2 \%$ - BVDV; in $14.7 \%$ - yeast fungi Candida albicans; in 13.6\% - Eimeria bovis; in 6.8\% - pathogenic Streptococcus spp. "Mono" infection of viral etiology (BVDV) was recorded in $10.2 \%$ of cases. Table 3 indicates that the antigenic picture is dominated by the association "BPIV3+ Staphylococcus spp.", which was diagnosed in $75 \%$ of sick animals. In one third $(32.9 \%)$ of parasitocenoses, the antigenic picture was composed of two taxonomic groups "Virus + Bacteria" - 25\% and "Bacteria + Coccidia" - 7.9\%. In 67.1\% of cases associations of viral antigens with microorganisms were registered: "Virus + Bacteria + Coccidia" $-6,8 \%$; "Virus + Virus + Bacteria" - 30,7\%; "Virus + Virus + Bacteria + pathogenic Fungi" $14,8 \%$; "Virus + Virus + Virus + Bacteria" is $14.8 \%$.

Therefore, comprehensive diagnostic investigations enabled us to determine the main link in the etiological structure of respiratory tract diseases and diseases of the gastrointestinal tract of young cattle: on farm-1 the etiological agents of respiratory tract 
diseases in calves are pathogenic microorganisms of the genus Staphylococcus spp. Diseases of the gastrointestinal tract in young animals have bacterial etiology Streptococcus spp., Staphylococcus spp. and hemolyzing E. coli.; the viral etiology of the disease was identified in $12 \%$ of cases. It should be also noted that in calves with a clinical picture of diseases of non-infectious etiology, bacterial infection is detected in $10.3 \%$ of cases, and coccidiosis is diagnosed in $2.3 \%$ of cases. On farm- 2 , in cases of respiratory tract diseases, $4.2 \%$ of cases are diagnosed with pathogens of the ARVI group in association with pathogenic microorganisms of the genus Staphylococcus spp. The lack of ARVI pathogens in the examined group of calves with non-infectious pathology indicates that the circulation of these infectious agents in the population is minimal and does not exceed $0.3 \%$ of the total number of young calves. The main etiological agent of diseases of the gastrointestinal tract are pathogenic microorganisms of the genus Staphylococcus spp. In diseases of non-infectious pathology, bacterial infection (Staphylococcus spp) is found in $9.4 \%$ of cases. On farm-3, in $37.2 \%$ of calves BPIV3 was detected as the leading cofactor in respiratory tract diseases; and in $20.6 \%$ of cases it was detected in association with pathogenic microorganisms such as Streptococcus spp., Staphylococcus spp. In $16.6 \%$ of cases, "Virus + Virus + Bacteria + Protozoal invasion" was diagnosed. BHV-1 was found in $13.8 \%$ of cases with respiratory tract diseases. The etiological agent of diseases of the gastrointestinal tract is parasitocenosis of «E. coli.K-99.+ Eimeria bovis». In young animals with diseases of non-infectious pathology, in $8.9 \%$ of cases $B V D V$ was diagnosed.

According to the results, therapeutic and preventive measures were designed to reduce the incidence of acute intestinal infections in young cattle by 1.5 times, and respiratory tract diseases by 1.3 times.

\section{Conclusion}

The results of these studies indicate that the key points in an objective assessment of the formation of the epizootic process are the identification of the species composition of pathogenic agents and studying of their circulation in the population of farm animals of a particular farm. The species variety of pathogens is individual for each farm, and therefore the likelihood of a combination of several pathogens in one macroorganism and the emergence of stable associations of pathogens varies significantly. Thus, it was demonstrated that associations of bacterial etiology (Staphylococcus spp., Streptococcus spp) predominate on the examined farm-1; Staphylococcus spp., Streptococcus spp., hemolytic E. coli.K-99 and, as cofactors antigens, pathogenic fungi of the genus Aspergillus and yeast fungi Candida albicans prevail on farm-2; BPIV3 in association with pathogenic microorganisms like Streptococcus spp., Staphylococcus spp - on farm-3. Moreover, the number of animals carrying $B H V-1$ and $B V D V$ pathogens differed: there were no such animals on farm-1; on farm-2, the number of calves carrying $B H V-1$ virus was $2.1 \%$; on farm-3 there were $8.9 \%$ of $B V D V$ virus carriers and $13.8 \%$ of $B H V-1$ virus carriers.

In our opinion, which in most cases coincides with the opinion of other researchers $[2,6$ - 13], the imperfection of methodological techniques for analyzing epizootological studies does not allow for a realistic assessment of the etiological structure of animal diseases within the administrative-territorial unit. Nevertheless, the research suggests that on farm-1 and farm-2 the level of circulation of $B H V-1$ and $B V D V$ in cattle populations is not more than $1-3 \%$. On farm-3 this level is much higher and ranges from 12 to $15 \%$ respectively.

Therefore, the implemented research gives the opportunity to (1) receive new data on the antigenic landscape of parasitocenoses on the territory of the Sverdlovsk region; (2) detail the species composition of pathogens in diseases of non-infectious pathology and 
infectious diseases of young cattle; and (3) develop and update the database to improve the methodology of epizootological studies analysis.

\section{References}

1. I.M. Donnik, A.S. Krivonogova, N.B. Musikhina, K.V. Moiseeva, A.A. Gordeev, A.G. Isaeva. Veterinariya Kubani, 5, 18-21 (2019) (In Russian)

2. K.P. Yurov, S.V. Alekseenkova, L.A. Mnikova, T.A. Ishkova. Trudy Vserossiyskogo NII eksperimental'noy veterinarii im. YA.R. Kovalenko, 80(1), 37-46 (2018) (In Russian)

3. N. Lacetera. Animal Frontiers, 9(1), 26-31 (2019)

4. G. Alpay, T. Eda, Y. Kadir. Tropical Animal Health and Production, 51(2), 297-302 (2018)

5. R. Besi, S. Terzić, T. Florijančić, J. Prpić, S.Ozimec, et al. Acta Veterinaria, 65-79 (2018)

6. A.P. Krasikov, I.G. Alekseeva. Online scientific method. Journal, of Omsk State Agrarian University, 1(1), (2015)

7. A.V. Nefedchenko, T.I. Glotova, A.G. Glotov. Vestnik KrasGAU, 1(124), 65-71 (2017) (In Russian)

8. A.P. Krasikov, I.G. Trofimov, I.G. Alekseeva. Vestnik OmGAU, 4(24), 165-172 (2016) (In Russian).

9. A.P. Poryvaeva, E.V. Pechura, I.A. Shkuratova. Reproduction in Domestic Animals, 54(3), 98 (2019)

10. K.P. Yurov, M.I. Gulyukin. Rossiyskaya sel'skokhozyaystvennaya nauka, 1, 59-63 (2018) (In Russian).

11. L. Colby, Z. Lois. ILAR Journal, 59(2), 134-143 (2018)

12. E.M. Galarza, R.M. Lizarraga, N. Streitenberger, G. Arriaga, G. Abraham, et al. Assessment of plasma zinc and total leukocyte count in calves experimentally infected with mannheimia haemolytica. Biological Trace Element Research Online First, 1-6 (2020)

13. J.F. Ridpath, W. Robert. J. of Veterinary Diagnostic Investigation, 32(4), 513-526 (2020) 